\title{
Koçaş Tarım İşletmesinde Yetiştirilen Siyah Alaca (Holştayn) Sığırlarda Bazı Süt Verimi Özellikleri ve İlişkili Genlerin Ekspresyonu
}

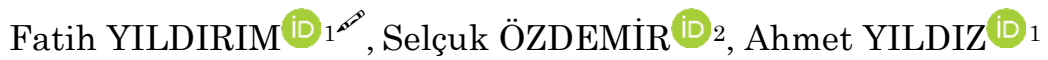

${ }^{1}$ Atatürk Üniversitesi, Veteriner Fakültesi, Zootekni Ana Bilim Dalı, Erzurum, ${ }^{2}$ Atatürk Üniversitesi, Veteriner Fakültesi, Genetik Ana Bilim Dalı, Erzurum

$\triangle$ : fatihyildirim@atauni.edu.tr

\section{ÖZET}

$\mathrm{Bu}$ çalışmanın amacı Aksaray Koçaş Tarım İşletmesi şartlarındaki Siyah Alaca sığırlarının bazı süt verimi özellikleri ve süt verimi ile ilişkili genlerin mRNA transkript seviyelerinin incelenmesi ve bazı çevre faktörlerinin etkilerinin araştırılmasıdır. Araştırma materyalini 2009-2015 yılları arasında Koçaş Tarım İşletmesinde bulunan toplam 324 baş Siyah Alaca ırkı sığırın, 1377 laktasyona ait 3452 kontroldeki süt verimi kaydı ile tüm hayvanlardan alınan kan örnekleri oluşturmuştur. Süt verimi özellikleri üzerine çevre faktörlerinin etkilerini değerlendirmede en küçük kareler metodu kullanılmıştır. Süt verimi ile ilişkili olan ATF3, CDKN1A ve PRL genlerine ait ifade düzeyleri qRT-PCR ile belirlenmiştir. En küçük kareler ortalamaları 100, 200 ve 305 günlük süt verimi için sırasıyla $2950.51 \pm 24.79 \mathrm{~kg}, 5594.28 \pm 45.09 \mathrm{~kg}, 7923.28 \pm 80.92 \mathrm{~kg}$; Laktasyon süt verimi, laktasyon süresi ve ortalama günlük süt verimi için sırasıyla, $7700.02 \pm 99.17 \mathrm{~kg}, 315.75 \pm 3.67$ gün ve $24.91 \pm 0.2 \mathrm{~kg}$ bulunmuştur. Yüksek süt verimine sahip ineklerde ilgili genlerin ifade düzeyleri, düşük verime sahip ineklere göre yüksek düzeyde bulunmuştur. Araştırma bulgularına göre yıllar içerisinde Siyah Alaca ineklerin süt verimini arttırmak için yapılan işlemlerin genel olarak olumlu yönde olduğu ve ATF3, CDKN1A ve PRL genlerinin, süt verimini arttırmaya yönelik yapılacak markör destekli seleksiyon ve ıslah çalışmalarına olumlu yönde katkı sağlayacağı sonucuna varılmıştır.

\section{DOI:10.18016/ ksudobil.333580}

\section{Makale Tarihçesi}

Geliş Tarihi : 08.08.2017

Kabul tarihi : 23.10.2017

Anahtar Kelimeler
Siyah Alaca,
süt verimi,
ATF3,
CDKN1A,
PRL

Araştırma Makalesi

Some Milk Yield Traits and Related Gene Expressions of Holstein Cattle Raised in Koçaş Agricultural Enterprise

\section{ABSTRACT}

The aim of this study was to investigate some milk production traits and milk production related gene mRNA transcript levels of Holstein cows in the conditions of Aksaray Koçaş agricultural enterprise and to investigate the effects of some environmental factors. Total 1349 milk yield record from 1377 lactation and blood samples of 324 Holstein cows raising in Koçaş agriculture enterprise between 20092015 years were used. The least squares method was used to assess the effects of environmental factors on milk characteristics. Milk production related ATF3, CDKN1A, and PRL gene expressions were identified by using qRT-PCR. The least squares means for milk yield of 100,200 and 305 days were $2950.51 \pm 24.79 \mathrm{~kg}, 5594.28 \pm 45.09 \mathrm{~kg}$ and $7923.28 \pm 80.92 \mathrm{~kg}$, respectively. Lactation milk yield, lactation period and average daily milk yield was found to be $7700.02 \pm 99.17$ $\mathrm{kg}, 315.75 \pm 3.67$ days and $24.91 \pm 0.2 \mathrm{~kg}$, respectively. According to qRT-PCR results, related gene expressions were up-regulated in high milk production cows compare to low milk production cows. According to the findings, it has been concluded that, Holstein cows are generally positive to improve milk yield over the years and ATF3, CDKN1A and PRL genes contribute positively to marker-assisted selection and breeding programs to improve milk yield.

Article History
Received : 08.08.2017
Accepted : 23.10.2017
Keywords
Holstein,
milk yield,
ATF3,
CDKN1A,
PRL

Research Article 
To Cite : Yıldırım F, Özdemir S, Yıldız A 2018. Koçaş Tarım İşletmesinde Yetiştirilen Siyah Alaca (Holştayn) Sı̆̆ırlarda Bazı Süt Verimi Özellikleri ve İlişkili Genlerin Ekspresyonu. KSÜ Tarım ve Doğa Derg 21(3): 353-362. DOI:10.18016/ ksudobil.333580

\section{GİŖ̧̇}

Dünyada süt verimi en yüksek sığır ırkları arasında yer alan ve özellikle ovalık birçok kesimde yetiştiriciliği yapılan Siyah Alaca (Holştayn, HolsteinFriesian) sığır ırkı, genel olarak iyi bakım, besleme ve serin iklim koşullarında geliştirilmiş bir ırktır (Anonim, 2017a). Almanya, Hollanda ve Danimarka'nın Kuzey Denizi kıyılarındaki ovalık kesimlerde yetiştirilen sığırlardan köken alan Siyah Alaca dünya'nın en yaygın yetiştiriciliği yapılan sığır ırkı olarak kabul edilmektedir. Başta süt olmak üzere, Holştayn sığır ırkları birçok verim özelliği ile diğer sığır ırklarının rekabet edemeyeceği seviyelerde yer almaktadır (Uslucan, 2017).

Türkiye'de sığırlardan elde edilen süt miktarının \%80-90' ı kültür ırkı ineklerden elde edilmektedir. Bu nedenle, sağmal inekler arasında en yaygın olarak yetiştirilen Holstayn ırkı sütçü sığırların, süt verimi üzerine etkili genetik ve çevre faktörlerinin belirlenmesi önem arz etmektedir (Gürses ve Bayraktar, 2012).

Kültür ırkı sığırlar arasında yer alan Siyah Alaca, ülkemizde sayısal varlığı açısından ön sıralarda yer almaktadır. Bu ırk özellikle Marmara, Ege ve Akdeniz bölgelerinde yetiştirilmekle birlikte diğer bölgelerde de bulunmaktadır. Bu bölgeler arasındaki çevre koşulları, yetiştiricilerin sosyo-ekonomik yapı farklılıkları ve yetiştiricilik şekilleri, hayvanların verim düzeylerinin farklı olmasına neden olmaktadır. $\mathrm{Bu}$ durum araştırmacılar tarafindan ülkemiz koşullarında Siyah Alaca sığırlarında yapılan çalışmalardan farklı sonuçların elde edilmesinin nedenlerinden biri olarak görülebilir (Uslucan, 2017).

Türkiye' de 2016 yılında büyükbaş hayvanlar arasında yer alan sığır sayısı 14 milyon 80 bin baş olarak tespit edilirken (\%46.8 Kültür, \%40.9 Melez, \%12.3 Yerli), toplam süt üretiminin 18 milyon 489 bin olduğu ve bu miktarın \%90.8‘ini inek, \%6.3'ünü koyun, \%2.6’sını keçi ve \%0.3’ünü manda sütünden oluştuğu bildirilmektedir (Anonim, 2017b).

Günümüze kadar yapılan araştırmalarda kültür ırkı sığırların adaptasyon çalışmalarının büyük bir kısmı kamuya ait işletmelerde yapılmıştır (Kaygısız ve ark., 2017). Özellikle Siyah Alaca ırkı sığırlarla ilgili süt verimi özelliklerini ortaya koymaya yönelik birçok araştırma mevcuttur. $\mathrm{Bu}$ konu üzerine farklı araştırmacılar tarafından yapılan çalışmaların sonuçları Çizelge 1'de özetlenmiştir.

Gelişen moleküler markör teknikleri (SSR, SNPs, GWAS, QTL) sayesinde sığırlarda süt verimi ve laktasyonla ilişkili birçok gen bulunmuştur (Georges ve ark., 1995; Andersson 2009; Schennink ve ark., 2009).

Çizelge 1. Siyah Alaca Irkı Sığırların Süt Verimi Özellikleri Üzerine Yapılan Araştırma Sonuçları

\begin{tabular}{|l|c|c|c|}
\hline \multicolumn{1}{|c|}{ Kaynaklar } & 305 günlük süt verimi (kg) & LSV (kg) & LS (gün) \\
\hline Akman ve ark.(2001) & $4564.8 \pm 42.04$ & $4925.86 \pm 39.71$ & $322.6 \pm 2.68$ \\
\hline Akkaş ve Şahin (2008) & $5735.67 \pm 70.49$ & $7574.39 \pm 55.22$ & $331.74 \pm 1.55$ \\
\hline Bakır ve ark. (2009) & $6810.14 \pm 56.38$ & $6427.90 \pm 75.03$ & $313.08 \pm 1.63$ \\
\hline Bakır ve Çetin (2003) & $6208.42 \pm 69.39$ & $7518.9 \pm 140.12$ & 330 \\
\hline Bayril ve Yılmaz (2010) & $7460.5 \pm 142.99$ & $6978.60 \pm 9.53$ & $358.17 \pm 0.12$ \\
\hline Cura (2016) & $5755.38 \pm 4.54$ & - & $303.4 \pm 3.04$ \\
\hline Çilek (2009) & $5606.92 \pm 75.49$ & $4966 \pm 32.96$ & $304.4 \pm 1.39$ \\
\hline Duru ve Tuncel (2002) & $4784 \pm 27.35$ & $6273.0 \pm 100.4$ & $301.7 \pm 3.8$ \\
\hline Erdem ve ark. (2007) & $6467.0 \pm 80.9$ & - & - \\
\hline Gürses ve Bayraktar(2012) & $7395.35 \pm 45.75$ & - & - \\
\hline Kaygısız (2013) & $5319.91 \pm 12.03$ & $6610.29 \pm 14.37$ & $360.33 \pm 0.25$ \\
\hline Keser (2016) & $5630.12 \pm 9.34$ & $7704.25 \pm 111.90$ & 325 \\
\hline Koçak ve ark. (2007) & - & $5969.75 \pm 255.24$ & - \\
\hline Koçak ve ark. (2008) & - & $6311.68 \pm 74.91$ & $311.02 \pm 32.42$ \\
\hline Özçakır ve Bakır (2003) & $6170.85 \pm 67.06$ & $7160.6 \pm 33.00$ & $330.3 \pm 1.5$ \\
\hline Özkök ve Uğur (2007) & $6729.2 \pm 33.3$ & - & - \\
\hline Parlak (2008) & $6884.111 \pm 162.88$ & $7473.4 \pm 59.6$ & - \\
\hline Sehar ve Özbeyaz (2005) & - & & $326.5 \pm 1.80$ \\
\hline Şahin ve Ulutaş (2010) & $6976.1 \pm 48.8$ & - & \\
\hline Şekerden (2002) & $5085.5 \pm 1010.2$ & & \\
\hline LSV: Laktasyon Süt Verimi, LS: Laktasyon Süresi & & \\
\hline
\end{tabular}


Son yıllarda yapılan genom boyu ilişkilendirme çalışmaları (GWAS) sonucu süt verimi ve süt kompozisyonu ile ilişkili birçok aday gen bulunmuştur (Yue ve ark., 2017; Dadousis ve ark., 2017). ATF3 (aktive edici transkripsiyon faktörü 3), CDKN1A (siklin bağımlı kinaz inhibitörü 1A) ve PRL (prolaktin) bu genlerden bazılarıdır (Han ve ark., 2017; Dong ve ark., 2013). Ancak süt verimi düşük ve yüksek olan sığırlarda ATF3, CDKN1A ve PRL genlerinin ekspresyon seviyeleri ile ilgili çalışmalar nadir olarak yapılmıştır (Dong ve ark., 2013; Han ve ark., 2017).

Sığırlarda 16. kromozomda bulunan ATF3 geni süt verimi ile ilişkili iki adet SNP içermektedir (Cole ve ark., 2011). Daha önce yapılan çalışmalarda ATF3 geninin lipit metabolizması, glikoprotein birikimi ve süt yağ formasyonu ile meme epitel hücrelerinin gelişmesiyle ilgili olan epitel hücre rejenerasyonunda görev aldığ Sığırlarda 23. kromozom da bulunan CDKN1A geninin süt proteini üzerine büyük genetik etkisinin olduğu daha önce doğrulanmıştır (Elo ve ark., 1999). Ayrıca bu genin yaklaşık 21-kD büyüklügünde ve hücre döngüsünde önemli rol oynayan p21 proteinini kodladığı bildirilmiştir (Bartek ve Lukas, 2001). PRL üremede, meme bezi gelişiminde, süt salgisının başlatılmasında ve memelilerde laktasyonun idame ettirilmesinde merkezi rol oynayan çok fonksiyonlu polipeptid bir hormondur. Klasik bir hipofiz hormonu olmasının yanı sıra, PRL süt proteinleri, laktoz ve lipidler de dahil olmak üzere pek çok süt bileşeninin sentezinden sorumludur (Le Provost ve ark., 1994; Dahl 2008). Bu nedenle sığır PRL geni, süt sığırlarında süt performans özelliklerini etkileyen kantitatif özellik lokusunun (QTL) bağlantı analizi için mükemmel bir aday olarak kabul edilir (Dong ve ark., 2013).

Son yllarda hayvanların bireysel olarak takip edilebilmesi ve kayıt altına alınabilmesine yönelik yapılan sağım ve sürü yönetim sistemleri araştırmacıların bu verileri kullanmasına yönlendirmiştir. Büyük işletmelerde çoğunlukla bu verilere dayanarak işletmelerine yön vermekte ve sürü yönetimleri için kararlar almaktadır. Ayrıca süt verimi yönünden yetiştirilen sığır populasyonlarında bu genlere ait ekspresyon seviyelerinin ortaya konması gelecekte yapılacak ıslah çalışmalarına genetik kaynak sağlaması yönünden faydalı olacaktır.

$\mathrm{Bu}$ çalışmada Siyah Alaca sığırlarının Tarım İşletmeleri Genel Müdürlüğü (TÍGEM)'ne bağlı Aksaray Koçaş Tarım İşletmesi Müdürlüğü (TİM) koşullarında elde edilen bazı süt verim özellikleri ve düşük ve yüksek süt verimli sığırların kanlarındaki ATF3, CDKN1A ve PRL genlerinin ekspresyon seviyelerinin belirlenmesi ve bazı çevre faktörlerinin etkilerinin ortaya konması amaçlanmıştır.

\section{MATERYAL ve METOT}

Araştırma materyalini, TİGEM'e bağlı Aksaray Koçaş
TíM' de yetiştirilen toplam 324 baş Holştayn inek ile bu hayvanlarm 2009-2015 yılları arasında 1377 laktasyona ait toplam 3452 kontroldeki süt verimi kaydı ile tüm hayvanlardan alınan kan örneklerinden oluşmuştur. Bu çalışma Atatürk Üniversitesi Hayvan Deneyleri Yerel Etik Kurul kararı ile yürütülmüştür (HADYEK-TR 2016/7).

\section{Süt Verimi Özellikleri}

Siyah Alaca ineklerinden toplanan tüm veriler TİGEM'e bağlı Koçaş Tarım İşletmesinden temin edilmiştir. Veriler işletmede bulunan bilgisayar destekli sağım sistemlerine (Westfalia Surge) bağlı sürü yönetimi programından (Dairy Plan C21) özel bir bilgisayar yazılımı yardımıyla dijital olarak alınmıştır. Süt verimi özelliklerinin belirlenmesinde, sürü yönetim programında en az 100 günlük süt verim kaydı mevcut tüm sağlıklı hayvanlar değerlendirilmiştir (Gürses ve Bayraktar, 2012).

Süt verimi özellikleri üzerine çevre faktörlerinin etkileri En Küçük Kareler Metodu kullanılarak belirlenmiştir. Kullanılan matematiksel model;

$\mathrm{Y}_{\mathrm{ijkl}}=\mu+\mathrm{a}_{\mathrm{i}}+\mathrm{b}_{\mathrm{j}}+\mathrm{c}_{\mathrm{k}}+\mathrm{e}_{\mathrm{ijkl}}$

şeklinde olup, bu modelde yer alan terimlerden $\mathrm{Y}_{\mathrm{ijkl}}=$ herhangi bir hayvanın incelenen verim özelliği değerini, $\mu$ : popülasyonun beklenen ortalamasını, ai : buzağılama yılının etkisini (i: 1-6; 2009/10, 2011, 2012, 2013, 2014, 2015), bj : buzağılama mevsiminin etkisini (j: 1-4; kış, ilkbahar, yaz, sonbahar), ck : laktasyon sırasının etkisini ( $\mathrm{k}: 1-6 ; 1,2,3,4,5,6)$, e eijkl = incelenen faktörler dışındaki faktörlerin etki miktarını (hata terimi) temsil etmektedir. İstatistiksel verilerin analizinde SPSS 20.0 paket programindan yararlanılmış olup, verilerin değerlendirilmesinde Genel Doğrusal Model uygulanmıştır (Version 20, IBM Corp., Armonk, NY, USA). İstatistiksel olarak önemli bulunan parametrelerde Tukey çoklu karşılaştırma testi kullanılarak alt gruplar karşılaştırılmıştır.

\section{Gen Ekspresyon Analizi}

\section{Total RNA İzolasyonu}

Süt verimi ve laktasyon performansı hesaplanan 324 baş sığırdan alınan kan örneklerinden 15 adet en yüksek süt verimi $(25-30 \mathrm{~kg})$ ve 15 adet düşük süt verimi (15-20 kg) olan ineklerden alınan kan örnekleri kullanıldı. Daha sonra bu kanlardan QIAamp RNA Blood Mini Kiti (Qiagen) kullanılarak total RNA izolasyonu kitin prosedürüne uygun olarak yapıldı. Total RNA izolasyonundan sonra RNA konsantrasyonu NanoDrop ile ölçüldü. Daha sonra RNA örneklerinin konsantrasyonları eşitlendi. Total RNA kalitesini kontrol etmek amaciyla RNA'lar $\% 1.5$ 'lik agaroz jel de 1XTBE solusyonu içerisinde 80 voltta bir saat yürütüldü ve jel görüntüleme sistemi ile görüntülenerek RNA kalitesi belirlendi. 


\section{Primerlerin Dizaynı}

Süt verimi ve laktasyon performansı ile ilişkili olan ATF3, CDKN1A ve PRL genlerine ait ekspresyon seviyelerinin Real Time PCR ile ölçülebilmesi için gerekli primer dizileri 'http://bioinfo.ut.ee/primer3' 0.4.0/" ilgili linkindeki Primer Design-3 programı kullanılarak tasarlandı. Tasarlanan primer dizileri daha önce herhangi bir çalışmada kullanılmamıştır.

\section{DNaz I uygulaması ve cDNA çevrimi}

İzole edilen RNA örneklerinde DNA kontaminasyonuna karşı DNaz I (Thermo Scientific) kullanıldı. Dnaz I uygulaması kitte verilen protokole uygun olarak yapıldı. Daha sonra bu RNA'lardan 2-5 $\mu \mathrm{g}$ alındı ve miScript Reverse Transcription Kiti (Qiagen) verilen protokole uygun şekilde kullanılarak cDNA sentezlendi. Revers transkripsiyon PCR şartları; $37{ }^{\circ} \mathrm{C}$ ' de 60 dakika, $95^{\circ} \mathrm{C}$ ' de 5 dakika. Elde edilen cDNA'nın saflığı ve miktarı spektrofotometrede yapılan 260-280 nm absorbans ölçümleri ile belirlendi ve cDNA'lar aynı oranlarda sulandırıldı. Daha sonra Real Time PCR çalışmalarında kullanılmak üzere -20 ${ }^{\circ} \mathrm{C}$ de muhafaza edildi.

\section{Real time PCR deneyleri}

ATF3, CDKN1A ve PRL genlerinin mRNA transkript seviyelerini ölçmek amacıyla CFX96 BioRad marka cihaz kullanılarak qRT-PCR yapıldı. İnternal kontrol olarak GAPDH geni kullanıldı. Real time PCR deneylerinde oluşturulan master mix içeriği; Syber
Green 2X Rox Dye Master mix (Qiagen), genler için tasarlanmış forward ve reverse primerler, template olarak cDNA'lar ve nükleaz free su. Master mixler hazırlandıktan sonra örnekler Real Time PCR cihazında analiz edildi ve elde edilen $\mathrm{Ct}$ değeleri 2DeltaDeltaCt metoduna uygun olarak hesaplanarak ilgili genlerin ekspresyon seviyeleri belirlendi (Livak ve Schmittgen, 2001). Ct değerlerinin dönüşüm hesaplaması Excel'de yapılmıştır. Excel'de kullanılan formül Çizelge 2'de belirtilmiştir.

Çizelge 2: Ct değerlerinin dönüşüm hesaplaması

\begin{tabular}{|c|c|c|}
\hline & Referans Örnek & $\begin{array}{l}\text { Hedef } \\
\text { örnek }\end{array}$ \\
\hline Referans örnek & $\mathrm{A}$ & $\mathrm{B}$ \\
\hline Hedef örnek & $\mathrm{C}$ & $\mathrm{D}$ \\
\hline $2^{\wedge}($ DeltaDeltaCT $)$ & (CTD-CTB)-(CTC-CTA) & \\
\hline
\end{tabular}

Genlerin reaksiyon koşulları; GAPDH için $94^{\circ} \mathrm{C} 15 \mathrm{~s} /$ $56^{\circ} \mathrm{C} 30 \mathrm{~s} / 72^{\circ} \mathrm{C} 30 \mathrm{~s}$ (40 döngü), CDKN1A için $94^{\circ} \mathrm{C} 15$ $\mathrm{s} / 55^{\circ} \mathrm{C} 30 \mathrm{~s} / 72^{\circ} \mathrm{C} 30 \mathrm{~s}$ (40 döngü), ATF3 için $94^{\circ} \mathrm{C} 15$ $\mathrm{s} / 55^{\circ} \mathrm{C} 30 \mathrm{~s} / 72^{\circ} \mathrm{C} 30 \mathrm{~s}$ (40 döngü), PRL için $94^{\circ} \mathrm{C} 15 \mathrm{~s}$ $/ 55^{\circ} \mathrm{C} 30 \mathrm{~s} / 72^{\circ} \mathrm{C} 30 \mathrm{~s}$ (40 döngü). Primer dizileri Çizelge 3'de gösterilmiştir.

İlgili genlere ait mRNA transkript değerleri için IBM SPSS (20.0) programı kullanılarak istatistiksel analiz yapıldı. mRNA transkript değerleri One Way ANOVA testi kullanılarak analiz edildi. Ayrıca genlere ait ekspresyon seviyeleri GrapPad 7.2 (California, USA) programı kullanılarak analiz edildi.

Çizelge 3: GAPDH, ATF3, CDKN1A ve PRL genlerine ait qRT-PCR Primer Dizileri

\begin{tabular}{|c|c|c|c|c|}
\hline Primer & Sekans (5'-3') & $\begin{array}{c}\text { Bağlanma } \\
\text { 1sısı }\end{array}$ & Uzunluk (bç) & Erişim numarası \\
\hline GAPDH & $\begin{array}{c}\text { F: AAGGTCGGAGTGAACGGATT } \\
\text { R: CGTTCTCTGCCTTGACTGTG }\end{array}$ & $56^{\circ}$ & 181 & NM_001034034.2 \\
\hline ATF3 & $\begin{array}{c}\text { F: CCTCGAGATGTCAGTCACCA } \\
\text { R: ACTCTTTCTGCAGGCACTCT }\end{array}$ & $55^{\circ}$ & 140 & NM_001046193.2 \\
\hline CDKN1A & $\begin{array}{c}\text { F: CTGCCTCTTTGGTCCAGTG } \\
\text { R: GTCTCGGTGACAAAGTCGAA }\end{array}$ & $55^{\circ}$ & 114 & NM_001098958.2 \\
\hline PRL & $\begin{array}{c}\text { F: CCAGGTATCCCTTCGAGACC } \\
\text { R: GGGTAGGAAGGGAGGAGGTA }\end{array}$ & $55^{\circ}$ & 164 & NM_173953.2 \\
\hline
\end{tabular}

\section{BULGULAR}

Koçaş Tarım İşletmesinde yetiştirilen Siyah Alaca sığırların 100, 200 ve 305 günlük süt verimine ait en küçük kareler ortalama verileri Çizelge 4'de, laktasyon sıralamasına göre gerçek laktasyon süt verimi (LSV), laktasyon süresi (LS), ortalama günlük süt veriminin (OGSV) en küçük kareler ortalamaları Çizelge 5'de ve ATF3, CDKN1A ve PRL genlerine ait mRNA transkript seviyeleri ise Çizelge 6'de sunulmuştur.

\section{Süt verimi özellikleri}

Araştırma sonucunda süt verimine göre buzağılama yılı, buzağılama mevsimi ve laktasyon sırası önem seviyeleri sırasıyla 100 günlük süt veriminde; $\mathrm{P}<0.01$, $\mathrm{P}<0.01, \mathrm{P}<0.001$ olarak belirlenirken, 200 günlük süt veriminde; $\mathrm{P}<0.001, \mathrm{P}<0.01, \mathrm{P}<0.001$ ve 305 günlük süt veriminde ise $\mathrm{P}<0.001, \mathrm{P}<0.05, \mathrm{P}<0.001$ düzeyinde tespit edilmiştir. 100, 200 ve 305 günlük süt verimi ortalamalar sirasiyla; 2950.51 $\pm 24.79,5594.28 \pm 45.09$, $7923.28 \pm 80.92$ olarak elde edilmiştir.

Laktasyon sırasına göre, gerçek laktasyon süt verimi $7700.02 \pm 99.17 \mathrm{~kg}$, laktasyon süresi $315.75 \pm 3.67$ gün ve ortalama günlük süt verimi $24.91 \pm 0.21 \mathrm{~kg}$ olarak belirlenirken, laktasyon sirasına göre veriler arasındaki farklılıkların ise yüksek düzeyde önemli $(\mathrm{P}<0.001)$ olduğu bulunmuştur. 
Çizelge 4. Süt Verimi ve Özelliklerine Ait En Küçük Kareler Ortalamaları $(\mathrm{X} \pm \mathrm{Sx})$

\begin{tabular}{|c|c|c|c|c|c|c|}
\hline \multirow[t]{2}{*}{ Buzağılama Yılı } & \multirow[t]{2}{*}{$\mathbf{N}$} & 100 gün (kg) & \multirow[t]{2}{*}{$\mathbf{N}$} & 200 gün $(\mathrm{kg})$ & \multirow[t]{2}{*}{$\mathbf{N}$} & 305 gün $(\mathrm{kg})$ \\
\hline & & $* *$ & & $* * *$ & & $* * *$ \\
\hline $2009 / 10$ & 200 & $2348.30 \pm 52.91^{\mathrm{d}}$ & 198 & $4575.94 \pm 99.68^{\mathrm{e}}$ & 152 & $6550.82 \pm 153.46^{\mathrm{d}}$ \\
\hline 2011 & 149 & $2793.52 \pm 60.57^{\mathrm{c}}$ & 147 & $5457.33 \pm 118.41^{\mathrm{cd}}$ & 107 & $7986.60 \pm 208.17^{\mathrm{bc}}$ \\
\hline 2012 & 284 & $2863.99 \pm 48.05^{\mathrm{c}}$ & 277 & $5377.55 \pm 94.85^{\mathrm{d}}$ & 180 & $7814.07 \pm 144.51^{\mathrm{c}}$ \\
\hline 2013 & 292 & $2956.27 \pm 55.95^{\mathrm{b}}$ & 281 & $5681.85 \pm 94.65^{\mathrm{bc}}$ & 182 & $7944.82 \pm 191.12^{\mathrm{abc}}$ \\
\hline 2014 & 279 & $3219.34 \pm 56.67^{\mathrm{b}}$ & 266 & $6043.26 \pm 102.38^{\mathrm{b}}$ & 174 & $8497.88 \pm 171.79^{\mathrm{ab}}$ \\
\hline 2015 & 173 & $3260.19 \pm 85.19^{a}$ & 93 & $6236.81 \pm 175.45^{\mathrm{a}}$ & 18 & $8636.07 \pm 434.86^{a}$ \\
\hline Buzağılama Mevsimi & & $* *$ & & $* *$ & & $*$ \\
\hline $\mathrm{K}_{1 \mathrm{~s}}$ & 303 & $2953.78 \pm 52.10^{\mathrm{ab}}$ & 294 & $5669.46 \pm 89.02^{\mathrm{a}}$ & 210 & $7810.76 \pm 156.94^{\mathrm{ab}}$ \\
\hline İlkbahar & 379 & $3072.40 \pm 47.91^{\mathrm{a}}$ & 366 & $5652.82 \pm 95.09^{\mathrm{a}}$ & 205 & $7817.57 \pm 184.07^{\mathrm{ab}}$ \\
\hline Yaz & 409 & $2853.04 \pm 43.83^{\mathrm{c}}$ & 324 & $5240.03 \pm 85.97^{b}$ & 206 & $7762.56 \pm 162.35^{b}$ \\
\hline Sonbahar & 286 & $2905.66 \pm 53.28^{\mathrm{bc}}$ & 278 & $5754.64 \pm 82.09^{\mathrm{a}}$ & 192 & $8325.46 \pm 136.19^{\mathrm{a}}$ \\
\hline Laktasyon No & & $* * *$ & & $* * *$ & & $* * *$ \\
\hline 1 & 320 & $2317.20 \pm 53.68^{c}$ & 313 & $4675.28 \pm 107.46^{c}$ & 213 & $6966.41 \pm 206.95^{\mathrm{b}}$ \\
\hline 2 & 315 & $2888.84 \pm 45.18^{\mathrm{b}}$ & 309 & $5520.56 \pm 86.19^{b}$ & 203 & $7715.45 \pm 145.24^{\mathrm{a}}$ \\
\hline 3 & 323 & $3201.67 \pm 45.73^{\mathrm{a}}$ & 316 & $6037.34 \pm 84.80^{\mathrm{ab}}$ & 209 & $8596.92 \pm 124.32^{\mathrm{a}}$ \\
\hline 4 & 267 & $3113.87 \pm 59.75^{\mathrm{a}}$ & 208 & $5823.83 \pm 103.00^{\mathrm{ab}}$ & 122 & $8385.47 \pm 166.75^{\mathrm{a}}$ \\
\hline 5 & 119 & $3108.60 \pm 65.73^{\mathrm{a}}$ & 95 & $5737.55 \pm 139.70^{\mathrm{ab}}$ & 57 & $7781.38 \pm 298.17^{\mathrm{a}}$ \\
\hline 6 & 33 & $3143.95 \pm 140.53^{\mathrm{a}}$ & 21 & $6097.87 \pm 282.03^{\mathrm{a}}$ & 9 & $8393.71 \pm 518.08^{\mathrm{a}}$ \\
\hline Genel Ortalama & 1377 & $2950.51 \pm 24.79$ & 1262 & $5594.28 \pm 45.09$ & 813 & $7923.28 \pm 80.92$ \\
\hline
\end{tabular}

Çizelge 5. Laktasyon Siralamasına Göre Gerçek Laktasyon Süt Verimi, Laktasyon Süresi ve Ortalama Günlük Süt Veriminin En Küçük Kareler Ortalamaları $(\mathrm{X} \pm \mathrm{Sx})$

\begin{tabular}{|c|c|c|c|c|}
\hline \multirow[t]{2}{*}{ Laktasyon No } & \multirow[t]{2}{*}{$\mathrm{N}$} & LSV (kg) & LS (gün) & OGSV (kg) \\
\hline & & $* * *$ & $* * *$ & $* * *$ \\
\hline 1 & 320 & $7308.87 \pm 146.07^{\mathrm{c}}$ & $352.09 \pm 5.41^{\mathrm{a}}$ & $20.98 \pm 0.31^{\mathrm{c}}$ \\
\hline 2 & 315 & $8364.70 \pm 147.23^{\mathrm{ab}}$ & $348.48 \pm 5.46^{\mathrm{a}}$ & $24.03 \pm 0.32^{\mathrm{b}}$ \\
\hline 3 & 323 & $8962.58 \pm 145.39^{a}$ & $350.44 \pm 5.39^{a}$ & $25.80 \pm 0.31^{\mathrm{ab}}$ \\
\hline 4 & 267 & $7726.02 \pm 159.92^{\mathrm{bc}}$ & $298.79 \pm 5.93^{b}$ & $26.63 \pm 0.34^{a}$ \\
\hline 5 & 119 & $7519.48 \pm 239.54^{\mathrm{bc}}$ & $296.91 \pm 8.88^{b}$ & $26.28 \pm 0.51^{\mathrm{a}}$ \\
\hline 6 & 33 & $6318.46 \pm 454.87^{d}$ & $247.79 \pm 16.85^{c}$ & $25.72 \pm 0.98^{\mathrm{ab}}$ \\
\hline Genel Ortalama & 1377 & $7700.02 \pm 99.17$ & $315.75 \pm 3.67$ & $24.91 \pm 0.21$ \\
\hline
\end{tabular}

Çizelge 6. ATF3, CDKN1A ve PRL Genlerine ait mRNA Transkript Seviyeleri En Küçük

Kareler Ortalamaları $(\mathrm{X} \pm \mathrm{Sx})$

\begin{tabular}{|c|c|c|}
\hline Gen & Düşük Verim (15-20 kg) & Yüksek Verim (25-30 kg) \\
\hline ATF3 & $0.84 \pm 0.004^{\mathrm{a}}$ & $2.05 \pm 0.02^{\mathrm{b}}$ \\
\hline CDKN1A & $0.72 \pm 0.005^{\mathrm{a}}$ & $2.47 \pm 0.016^{\mathrm{b}}$ \\
\hline PRL & $1.0 \pm 0.021^{\mathrm{a}}$ & $1.5 \pm 0.038^{\mathrm{b}}$ \\
\hline $\begin{array}{l}\text { a: Düşük verimli sığırlarda ilgili genlerin ekspresyon seviyleri. } \\
\text { b: Yüksek verimli sığırlarda ilgili genlerin ekspresyon seviyeleri. }\end{array}$ \\
\hline
\end{tabular}

\section{Gen Ekspresyon Analizi}

Çalışma sonucunda elde edilen veriler incelendiğinde, süt verimi yüksek olan sığırlarda süt verimi ile ilişkili olan ATF3 ve CDKN1A genlerinin ekspresyon seviyeleri süt verimi düşük olan sığırlara göre istatistiksel olarak önemli bulunmuştur (sırasıyla; $\mathrm{P}<0.01, \quad \mathrm{P}<0.001$ ) (Şekil 1A ve 1B). Laktasyon performansı ile ilişkili olan PRL genine ait ekspresyon seviyesi ise süt verimi yüksek olan sığırlarda, süt verimi düşük olan sığırlara göre istatistiksel olarak önemli bulunmuştur $(\mathrm{P}<0.05)$ (Şekil 1C). 



Şekil 1. Düşük ve yüksek süt verimli Siyah Alaca sığırlarında ATF3, CDKN1A ve PRL genlerine ait mRNA transkript seviyeleri. Değerler 3 bağımsız örneklemin ortalama \pm SD' sini temsil eder; Hata çubukları standart sapmayı gösterir. İstatistiksel anlamlılık $\left(* \mathrm{P}<0.05,{ }^{* *} \mathrm{P}<0.01\right.$ ve $* * *$ $\mathrm{P}<0.001$ ), faktöriyel ANOVA ile analiz edildi. A) ATF3 geninin göreceli mRNA ekspresyon seviyelerini temsil eder. B) CDKN1A geninin göreceli mRNA ekspresyon seviyelerini temsil eder. C) PRL geninin göreceli mRNA ekspresyon seviyelerini temsil eder.

\section{TARTIŞMA}

\section{Süt verimi özellikleri}

$\mathrm{Bu}$ araştırmadan elde edilen 100 ve 200 günlük süt verimi değerleri sınırlı sayıda araştırmacı tarafından incelenirken 305 günlük süt verimi birçok araştırmacı tarafından çalışılmıştır. Bu çalışmada 100 ve 200 günlük süt verimi için elde edilen değerler Gürses ve Bayraktar (2012) tarafından bildirilen değerlerden (100 gün: 2719.66 $\pm 13.52,200$ gün: $5246.94 \pm 25.69)$ yüksek bulunurken, aynı işletmede (Koçaş TiM) farklı yıllarda elde edilen değerlerin (100 gün: $2896 \pm 18.76$, 200 gün: 5661 \pm 35.50$)$ bu çalışma ile yakın olduğu tespit edilmiştir. Araştırmacıların 100 ve 200 günlük süt verimine (Gürses ve Bayraktar, 2012) göre buzağılama yılı, buzağılama mevsimi ve laktasyon sayısı bu çalışma sonuçlarına benzer şekilde önemli seviyelerde bulunmuştur. Çalışmadan elde edilen 305 günlük süt verimi $4500-7500 \mathrm{~kg}$ arasında bildirilen araştırmalardan yüksek (Duru ve Tuncel, 2002; Akman ve ark., 2001; Şekerden, 2002; Bakır ve Çetin, 2003; Özçakır ve Bakır, 2003; Erdem ve ark., 2007; Özkök ve Uğur, 2007; Çilek, 2009; Şahin ve Ulutaş, 2010; Parlak, 2008; Bakır ve ark., 2009; Bayril ve Yılmaz, 2010; Gürses ve Bayraktar, 2012; Akkaş ve Şahin, 2008; Cura, 2016; Keser, 2016; Kaygısız, 2013), Koçaş TİM için 8078 463.42 olarak bildirilenden düşük (Gürses ve Bayraktar, 2012) değerler almıştır. Araştırmada bulduğumuz laktasyon süt verimi ise birçok araştırmacının önceki yıllarda elde ettiği verilerinden (Duru ve Tuncel, 2002; Akman ve ark., 2001; Bakır ve Çetin, 2003; Özçakır ve Bakır, 2003; Seher ve Özbeyaz, 2005; Erdem ve ark., 2007; Özkök ve Uğur, 2007; Koçak ve ark., 2008; Şahin ve Ulutaş, 2010; Bakır ve ark., 2009; Bayril ve Yılmaz, 2010; Cura, 2016; Keser, 2016) yüksek değerde iken bazı araştırma sonuçlarına ise benzer sonuçlar göstermiştir (Koçak ve ark., 2007). Oluşan bu sonuçlara göre genotipik ve çevre faktörleri yönünden işletme yöneticilerinin seneler geçtikçe süt verimini arttırmak için yaptığı işlemlerin olumlu yönde sonuç verdiği söylenebilir.

$\mathrm{Bu}$ çalışma ile buză̆ılama yılının birçok araştırmalarda benzer şekilde 305 günlük süt verimi (Gürses ve Bayraktar, 2012; Şekerden, 2002; Çilek, 2009), laktasyon süt verimi (Seher ve Özbeyaz, 2005, Koçak ve ark., 2008) ve hem 305 gün hem de laktasyon süt verimi üzerine etkisinin önemli olduğunu bildirilirken (Duru ve Tuncel, 2002; Akman ve ark., 2001; Bakır ve Çetin, 2003; Özçakır ve Bakır, 2003; Erdem ve ark., 2007; Özkök ve Uğur, 2007; Şahin ve Ulutaş, 2010; Bakır ve ark., 2009; Bayril ve Yılmaz, 2010; Cura, 2016; Keser, 2016), bazı araştırmacılar ise buzağılama yılının 305 günlük süt verimi (Akkaş ve Şahin, 2008; Parlak, 2008) ve laktasyon süt verimi (Koçak ve ark., 2007) üzerine etkisini önemsiz olarak tespit etmiştir. Günümüze kadar yapılan çoğu araştırmada genel olarak yıllar ilerledikçe süt verimi yönünden bir ilerlemenin olduğu gözlenmiş ve bu araştırmanın bulgularında da bu yönlü bir sonuç elde edilmiştir. Bu nedenle gelecekte daha iyi süt verimi sonuçlarının elde edilebileceği düşünülebilir.

Buzağllama mevsiminin süt verimi üzerine etkisinin 100 günlük verimde ilkbahar $>$ kış>sonbahar $>$ yaz, 200 günlük verimde sonbahar $>$ kış>ilkbahar $>$ yaz ve 305 günlük süt veriminde sonbahar $>$ ilkbahar $>$ kış>yaz şeklinde sıralandığı bu araştırmada tespit edilirken, bazı araştırmacılar mevsimlerin sıralamasını 100 günlük verim için kış>İlkbahar>sonbahar>yaz, 200 ve 305 günlük verimler için ise kış>sonbahar>ilkbahar>yaz şeklinde olduğunu 
bildirmişlerdir (Gürses ve Bayraktar, 2012). Birçok araştırmacı mevsimlerin 305 günlük süt verimi (Gürses ve Bayraktar, 2012; Şekerden, 2002; Özçakır ve Bakır, 2003; Akkaş ve Şahin, 2008; Çilek, 2009), laktasyon süt verimi (Koçak ve ark., 2007), hem 305 hem de laktasyon süt verimi (Erdem ve ark., 2007, Özkök ve Uğur, 2007; Şahin ve Ulutaş, 2010; Bayril ve Yllmaz, 2010; Cura, 2016; Keser, 2016) üzerine etkisinin önemli olduğunu bildirmişlerdir. $\mathrm{Bu}$ bulguların aksine bazı araştırmacılar ise mevsimlerin 305 günlük süt verimi (Parlak, 2008), laktasyon süt verimi (Koçak ve ark., 2008), hem 305 hem de laktasyon süt verimine (Duru ve Tuncel, 2002; Bakır ve Çetin, 2003; Bakır ve ark., 2009) etkisini önemsiz olduğunu tespit etmişlerdir. Genel olarak elde edilen sonuçlara göre Siyah Alaca ineklerin süt verimlerinin sıcak aylarda olumsuz yönde, llık ve soğuk aylarda olumlu yönde etkilendiği elde edilen sonuçlara göre söylenebilir. Ayrıca, mevsimlerin süt verimi seviyeleri üzerine etkilerinin yönetimsel farklılıklardan kaynaklandığı düşünülebilir.

Laktasyon sayısına göre 100, 200 ve 305 günlük süt verimi sıralamasını bazı araştırmacılar sırasıyla $2>3>4>5>1>6+, \quad 2>3>1>4>5>6+, \quad 2>1>3>4>5>6+$ şeklinde siralarken (Gürses ve Bayraktar, 2012), bu çalışmada $3>6>4>5>2>1,6>3>4>5>2>1,3>6>4>5>2>1$ olarak siralanmıştır. Laktasyon sırasının 100 ve 200 günlük süt verimine etkisini, bazı araştırmacılar bu çalışmaya paralel olarak yüksek düzeyde önemli bulmuştur (Gürses ve Bayraktar, 2012). Birçok araştırmacı laktasyon sayısının 305 günlük süt verimi (Şekerden, 2002, Akkaş ve Şahin, 2008; Çilek, 2009; Özçelik ve Arpacık, 2000), laktasyon süt verimi (Koçak ve ark., 2008), hem 305 hem de laktasyon süt verimi (Duru ve Tuncel, 2002; Akman ve ark., 2001; Özçakır ve Bakır, 2003; Erdem ve ark., 2007; Özkök ve Uğur, 2007; Şahin ve Ulutaş, 2010; Bakır ve ark., 2009; Bayril ve Yllmaz, 2010; Cura, 2016; Keser, 2016) üzerine etkisinin önemli olduğunu bildirmişlerdir. Tersine bazı araştırmacılar ise laktasyon sayısının, 305 günlük süt verimine (Parlak, 2008), laktasyon süt verimine (Seher ve Özbeyaz, 2005; Koçak ve ark., 2007), hem 305 hem de laktasyon süt verimine (Bakır ve Çetin, 2003) etkisini önemsiz olarak tespit etmiştir.

Laktasyon süresini bazı araştırmalar ile gün olarak karşılaştırdığımızda, bu araştırma sonuçlarından bazı araştırma değerlerinin düşük (Duru ve Tuncel, 2002; Seher ve Özbeyaz, 2005; Erdem ve ark., 2007; Çilek, 2009), bazılarının yüksek (Akman ve ark., 2001; Özkök ve Uğur, 2007; Koçak ve ark., 2007; Şahin ve Ulutaş, 2010; Bakır ve ark., 2009; Bayril ve Yılmaz, 2010; Akkaş ve Şahin, 2008; Cura, 2016; Keser, 2016) ve bazılarının ise yakın olduğu bulunurken (Bakır ve Çetin, 2003; Özçakır ve Bakır, 2003), ortalama günlük süt verimine göre ise bu araştırmadaki verilerden, bazı araştırma değerlerinin yüksek (Melendez ve Pinedo, 2015), bazılarının ise düşük (Orhan ve Kaşıkçı, 2002;
Aytekin ve ark., 2016) olduğu gözlenmiştir. Laktasyon süresi ortalamasının ideal süreden (305 gün) genel olarak ilk laktasyonlarda uzun olması, özellikle 5 . laktasyondan sonra hayvan sayısının azalmasinın önemli bir nedeni olarak görülebilir.

\section{Gen Ekspresyon Analizi}

Çalışma sonucunda süt verimi düşük ve yüksek olan Siyah Alaca ineklerde ATF3, CDKN1A ve PRL genlerinin mRNA transkript seviyeleri belirlendi. Daha önce yapılan bir çalışmada ATF3 geninin siklin D1 ifadesini aktive ettiği ve böylece hepatoselüler çoğalmanın stimüle edildiği bildirilmiştir (Allan ve ark., 2001). Karaciğer bilindiği üzere yağ asidi alımı, sentezi ve oksidasyonu, gliserolipid sentezi ve lipid metabolizmasında önemli bir rol oynamaktadır (Nguyen ve ark., 2008). Invernizzi ve ark. (2010, 2012) tarafından yapılan çalışmalarda ATF3'ün, laktasyon sırasında endoplazmik retikulum stres yolağına katılarak süt yağının sentezini modüle ettiği rapor edilmiştir. Sütün oluşumu için gerekli olan biyokimyasal moleküllerinden bir tanesi yağ asitleridir (Gu ve ark.,2017). Dolayısıyla ATF3 geni hepatositlerin gelişim ve çoğalmasını sağlayarak yağ asidi sentezini stimüle eder ve bu sayede süt oluşum mekanizmasında rol oynayabilir. Li ve Capuco (2008), tarafından sığır meme bezinde östrojen yanıt veren genler için yapılan sistematik araştırmada 23 adet transkripsiyon mekanizması belirlendi ve bu mekanizmalarda CDKN1A geninin, hücre döngüsü ve hücre hareketi gibi yolaklarda düzenleyici olarak rol oynadığı rapor edildi. Yine aynı çalışmada bu genin meme bezi gelişiminde önemli bir rol oynayabileceği ileri sürüldü. Meme bezleri sütün fizyolojik oluşumunda anahtar rol oynamaktadır (Singh ve ark., 2017). CDKN1A geninin meme bezlerinin gelişimini sağlayarak süt oluşum mekanizmasında düzenleyici olarak görev alabileceği ifade edilmiştir. Han ve ark. (2017) tarafından Çin'deki Siyah Alaca sığırları üzerine yapılan bir çalışmada ATF3 ve CDKN1A genlerinin süt verimi üzerine genetik etkisinin olduğunu ve bu genin marköre dayalı ıslah çalışmalarında kullanılabileceğini bildirmişlerdir. $\mathrm{Bu}$ bilgiler ışığında, bu çalışmada elde edilen ATF3 ve CDKN1A genlerinin süt verimi yüksek Siyah Alaca ineklerindeki yüksek seviyedeki ekspresyonu bu genlerin marköre dayalı ıslah ve seleksiyon çalışmalarında kullanılma potansiyelini güçlendirmektedir. Ayrıca bu genlerin süt verimi yüksek sığırlarda yüksek oranda ekspresyon seviyesine sahip olması, genotipik olarak süt verimine pozitif yönde katkı sağlamasının bir kanıtı olabilir. Ancak bu durumun kesinlik kazanması için daha detaylı çalışmaların yapılmasına ihtiyaç duyulmaktadır.

PRL geni elektrolit dengesi, büyüme, gelişme, endokrinoloji, metabolizma, beyindeki çeşitli işlevlerin 
düzenlenmesi, annelik davranışının korunması, üreme ve immüno-regülasyon gibi birçok biyolojik süreci etkilemektedir (Bole-Feysot ve ark., 1998). Dong ve ark. (2013) tarafindan Cin'de yetiştirilen Siyah Alaca sığırları üzerine yaptıkları bir çalışmada PRL geninde laktasyon performansı ile ilişkili SNP'ler tespit edilmiş ve bu genin sığırlarda süt üretimi ve laktasyon performansı için markör olabileceği ileri sürülmüştür. Prolaktin hormonu PRL geni tarafindan kodlanmaktadır. Bu hormon süt oluşumunu indüklemektedir (Patel ve Chauhan, 2017). Dolayısıyla PRL geni süt oluşum mekanizmasına doğrudan olumlu katkı yapabilir. Bu çalışmada elde edilen PRL genine ait ekspresyon sonuçları bu genin süt verimi yönünde yetiştirilen sığır popülasyonlarında laktasyon performansı için markör olarak kullanılabileceğini göstermektedir.

\section{SONUÇ}

Koçaş Tarım İşletmesinde elde edilen verilere göre yıllar içerisinde süt verimini arttırmak için yapılan işlemlerin genel olarak olumlu yönde olduğu ancak gen ekspresyonu yönünden bakıldığında tekrar gözden geçirilmesi gerektiği tespit edildi. Siyah Alaca ineklerin süt verimlerinin yıldan ylla arttı̆̆ sıcaklıktan (özellikle yaz aylarında) hayvanların büyük oranda etkilendiği ve ineklerin en yüksek süt verimine 3. laktasyon da ulaştığı gözlendi. Gen ekspresyon analizi yönünden; ATF3, CDKN1A ve PRL genlerinin süt verimi ve laktasyon performansı yüksek olan Siyah Alaca sığırlarda, düşük olan sığırlara göre yüksek seviyede ifade edildiği tespit edildi. Çalışmadan elde edilen bu sonuçlar ile ATF3, CDKN1A ve PRL genlerinin sığırlarda süt verimi üzerine yapılacak marköre dayalı ıslah ve seleksiyon çalışmalarında kullanılma potansiyelini güçlendirdiği söylenebilir.

Bu bulgular ışı̆̆ı altında, süt verimi ve gen ekspresyon analizi yönünden sürü idaresinin ve işletmelerin iklim koşullarının dikkate alınması, belli bir genotipe sahip Siyah Alaca ineklerin süt verimlerinde daha iyi sonuçlar elde etmek için önem arz etmektedir.

\section{KAYNAKLAR}

Akkaş Ö, Şahin EH 2008. Holştayn Irkı Sığırlarda Bazı Verim Özellikleri. Kocatepe Vet J, 1(1): 25-31.

Akman N, Ulutaş Z, Efil H, Biçer S 2001. Gelemen Tarım İşletmesinde Yetiştirilen Siyah Alaca Sürüsünde Süt ve Döl Verimi Özellikleri. Atatürk Üniv Ziraat Fak Derg, 32(2): 173-179.

Allan AL, Albanese C, Pestell RG, LaMarre J 2001. Activating Transcription Factor 3 Induces DNA Synthesis and Expression of Cyclin D1 in Hepatocytes. J Biol Chem, 276(29): 27272-27280.

Andersson L 2009. Genome-wide Association Analysis in Domestic Animals: A Powerful Approach for
Genetic Dissection of Trait Loci. Genetica, 136(2): 341-349.

Anonim 2017a. Breeds of Livestock - Holstein Cattle. http://www.ansi.okstate.edu/breeds/cattle/holstein, (Erişim tarihi: 13.07.2017).

Anonim 2017b. Türkiye İstatistik Kurumu Hayvancılık İstatistikleri. http://www.tuik.gov.tr (Erişim tarihi: 13.07.2017).

Aytekin I, Mammadova NM, Altay Y, Topuz D, Keskin I 2016. Determination of The Factors Effecting Lactation Milk Yield of Holstein Friesian Cows by The Path Analysis. Selcuk J Agr Food Sci, 30(1): 4448.

Bakır G, Çetin M 2003. Reyhanlı Tarım İşletmesinde Yetiştirilen Siyah Alaca Sığırlarda Süt ve Döl Verim Özellikleri. Turk J Vet Anim Sci, 27: 173180.

Bakır G, Kaygısız A, Çilek S 2009. Milk Yield Traits of Holstein Cattle Reared at Tahirova State Farm in Balikesir Province in Turkey. J Anim Vet Advances, 8(11): 2369-2374.

Bartek J, Lukas J 2001. Pathways Governing G1/S Transition and Their Response to DNA Damage. FEBS Lett, 490(3): 117-122.

Bayril T, Yılmaz O 2010. Kazova Vasfi Diren Tarım İşletmesinde Yetiştirilen Siyah Alaca Sığırların Döl Verimi Özellikleri. YYU Vet Fak Derg, 21(3): 163167.

Bole-Feysot C, Goffn V, Edery M, Binart N 1998. Prolactin (PRL) and Its Receptor: Actions, Signal Transduction Pathways and Phenotypes Observed in PRL Receptor Knockout Mice. Endocr Rev, 19: 225-268.

Cole JB, Wiggans GR, Ma L, Sonstegard TS, Lawlor TJ Jr, Crooker BA, Van Tassell CP, Yang J, Wang S, Matukumalli LK 2011. Genome-Wide Association Analysis of Thirty One Production, Health, Reproduction and Body Conformation Traits in Contemporary U.S. Holstein cows. BMC Genomics, 12: 408.

Cui XG, Hou YL, Yang SH, Xie Y, Zhang SL, Zhang Y, Zhang Q, Lu XM, Liu GE, Sun DX 2014. Transcriptional Profiling of Mammary Gland In Holstein Cows With Extremely Different Milk Protein and Fat Percentage Using RNA Sequencing. BMC Genomics, 15: 226.

Cura EÖ 2016. Trakya Bölgesinde Yetiştirilen Siyah Alaca Süt Sığırlarında Döl ve Süt Verimlerinin Bazı Sistematik Faktörler Açısından Değerlendirilmesi. NKÜ. Fen Bil. Ens., Zootekni ABD, Yüksek Lisans Tezi, Tekirdağ.

Çilek S 2009. Milk Yields Traits of Holstein Cows Raised at Polatlı State Farm in Turkey. J Anim Vet Advances, 8(1): 6-10.

Dadousis C, Pegolo S, Rosa GJM, Bittante G, Cecchinato A 2017. Genome-Wide Association And Pathway-Based Analysis Using Latent Variables Related To Milk Protein Composition And 
Cheesemaking Traits in Dairy Cattle. Journal of Dairy Science, 10.3168/jds.2017-13219.

Dahl GE 2008. Effects of Short Day Photoperiod on Prolactin Signaling in Dry Cows: A Common Mechanism Among Tissues and Environments? J Anim Sci, 86: 13.

Dong CH, Song XM, Zhang L, Jiang JF, Zhou JP, Jiang YQ 2013. New Insights into the Prolactin-RsaI (PRL-RsaI) Locus in Chinese Holstein Cows and Its Effect on Milk Performance Traits. Genet Mol Res, 12 (4): 5766-5773.

Duru S, Tuncel E 2002. Koçaş Tarım İşletmesinde Yetiştirilen Siyah-Alaca Sığırların Süt ve Döl Verimleri Üzerine Bir Araştırma (1. Süt Verim Özellikleri). Turk J Vet Animal Sci, 26: 97-101.

Elo KT, Vilkki J, de Koning DJ, Velmala RJ, MakiTanila AV 1999. A Quantitative Trait Locus for Live Weight Maps to Bovine Chromosome 23. Mamm Genome,10(8): 831-835.

Erdem H, Atasever S, Kul E 2007. Gökhöyük Tarım İşletmesinde Yetiştirilen Siyah Alaca Sığırların Süt ve Döl Verim Özellikleri 1. Süt Verim Özellikleri. OMÜ Zir Fak Derg, 22(1): 41-46.

Georges M, Nielsen D, Mackinnon M, Mishra A, Okimoto R, Pasquino AT, Sargeant LS, Sorensen A, Steele MR, Zhao X 1995. Mapping Quantitative Trait Loci Controlling Milk Production in Dairy Cattle by Exploiting Progeny Testing. Genetics, 139(2): 907-920.

Gu M, Cosenza G, Nicolae I, Bota A, Guo Y, Di Stasio L, Pauciullo A 2017. Transcript Analysis at DGAT1 Reveals Different mRNA Profiles in River Buffaloes with Extreme Phenotypes for Milk Fat. J Dairy Sci, 0022-0302(17): 30731-30732.

Gürses M, Bayraktar M 2012. Türkiye'de Farklı Bölgelerde Yetiştirilen Holştayn Sığırlarda Bazı Süt ve Döl Verimi Özellikleri. Kafkas Univ Vet Fak Derg, 18(2): 273-280.

Han B, Liang W, Liu L, Li Y, Sun D 2017. Determination of Genetic Effects of ATF3 and CDKN1A Genes on Milk Yield and Compositions in Chinese Holstein Population. BMC Genetics, 18: 47.

Invernizzi G, Naeem A, Loor JJ 2012. Short Communication: Endoplasmic Reticulum Stress Gene Network Expression in Bovine Mammary Tissue During the Lactation Cycle. J Dairy Sci, 95(5): 2562-2566.

Invernizzi G, Thering BJ, McGuire MA, Savoini G, Loor JJ 2010. Sustained Upregulation of StearoylCoA Desaturase in Bovine Mammary Tissue With Contrasting Changes in Milk Fat Synthesis And Lipogenic Gene Networks Caused by Lipid Supplements. Funct Integr Genomics, 10(4): 561575.

Kaygisız A, Yılmaz İ, Koşum S 2017. Şanlıurfa İlinde Siyah Alaca Irkı Sığırların Yetiştirici Şartlarında Bazı Adaptasyon Özellikleri. KSÜ Doğa Bil Derg, 20(2): 133-136.
Kaygisiz A 2013. Estimation of Genetic Parameters and Breeding Values for Dairy Cattle Using Testday Milk Yield Records. J Anim Plant Sci, 23: 345349.

Keser M 2016. Tekirdă̆ İlinde Farklı İşletme Büyüklüklerinde Yetiştirilen Siyah Alaca Süt Sığırlarının Döl Ve Süt Verim Özelliklerin Belirlenmesi. NKÜ. Fen Bil. Ens., Zootekni ABD, Yüksek Lisans Tezi, Tekirdağ.

Koçak S, Tekerli M, Özbeyaz C, Demirhan İ 2008. Lalahan Merkez Hayvancılık Araştırma Enstitüsünde Yetiştirilen Holştayn, Esmer ve Simental Sığırlarda Bazı Verim Özellikleri. Lalahan Hay Araşt Enst Derg, 48(2): 51-57.

Koçak S, Yüceer B, Uğurlu M, Özbeyaz C 2007. Bala Tarım İşletmesinde Yetiştirilen Holştayn İneklerde Bazı Verim Özellikleri. Lalahan Hay Araşt Enst Derg, 47(1): 9-14.

Le Provost F, Leroux C, Martin P, Gaye P, Djiane J 1994. Prolactin Gene Expression in Ovine and Caprine Mammary Gland. Neuroendocrinology, 60: 305-313

Li RW, Capuco AV 2008. Canonical Pathways And Networks Regulated by Estrogen in The Bovine Mammary Gland. Funct Integr Genomics, 8(1): 5568.

Livak KJ, Schmittgen TD 2001. Analysis of Relative Gene Expression Data Using Real-Time Quantitative PCR and The 2 (-Delta Delta C(T)) Method. Methods, 25: 402-408.

Melendez P, Pinedo PJ 2015. Effect of Dry Beet Pulp on Milk Yield and Milk Composition in Chilean Holstein cows. J Appl Anim Res, 43(3): 261-265.

Nguyen P, Leray V, Diez M, Serisier S, Le Bloc'h J, Siliart B, Dumon H 2008. Liver Lipid Metabolism. J Anim Physiol Anim Nutr (Berl), 92(3): 272-283.

Orhan H, Kaşıkçı D 2002. Path, Korelasyon ve Kısmi Regresyon Katsayılarının Karşılaştırılmalı Olarak İncelenmesi. Hayvansal Üretim, 43(2): 68-78.

Özçakır A, Bakır G 2003. Tahirova Tarım İşletmesinde Yetiştirilen Siyah Alaca Sığırların Döl ve Süt Verim Özellikleri (1. Süt Verim Özellikleri). Atatürk Üniv Ziraat Fak Derg, 34(3): 145-149.

Özçelik M, Arpacık R 2000. Siyah Alaca Sığırlarda Laktasyon Sayısının Süt ve Döl Verimine Etkisi. Turk J Vet Animal Sci, 24: 39-44.

Özkök H, Uğur F 2007. Türkiye'de Yetiştirilen Esmer ve Siyah Alaca Sığırlarda Süt Verimi, İlk Buzağılama Yaşı ve Servis Periyodu. Atatürk Üniv Ziraat Fak Derg, 38(2): 143-149.

Parlak N 2008. Afyonkarahisar İlinde Yetiştirilen Siyah Alaca İneklerin Süt ve Döl Verimleri Üzerine Farklı Çevre Faktörlerinin Etkisi. AKÜ. Sağlık Bil. Ens, Zootekni ABD, Yüksek Lisans Tezi, Afyonkarahisar.

Patel JB, Chauhan JB 2017. Polymorphism of the Prolactin Gene and Its Relationship with Milk 
Production in Gir and Kankrej Cattle. J Nat Sci Biol Med, 8(2):167-170.

Schennink A, Bovenhuis H, Leon-Kloosterziel KM, van Arendonk JA, Visker MH 2009. Effect of Polymorphisms in the FASN, OLR1, PPARGC1A, PRL and STAT5A Genes on Bovine Milk-Fat Composition. Anim Genet, 40(6): 909-916.

Sehar Ö, Özbeyaz C 2005. Orta Anadoludaki Bir İşletmede Holştayn Irkı Sığırlarda Bazı Verim Özellikleri. Lalahan Hay Araşt Enst Derg, 45(1): 919.

Singh K, Phyn CVC, Reinsch M, Dobson JM, Oden K, Davis SR, Stelwagen K, Henderson HV, Molenaar AJ 2017. Temporal and Spatial Heterogeneity in Milk and Immune-related Gene Expression During Mammary Gland Involution in Dairy Cows. J Dairy Sci, 0022-0302(17): 30663.

Şahin A, Ulutaş Z 2010. Polatlı Tarım İşletmesinde Yetiştirilen Siyah Alaca İneklerde Süt ve Döl Verim
Özellikleri. Anadolu Tarım Bilim Derg, 25(3): 202212.

Şekerden Ö 2002. Siyah Alaca Sığırlarda Süt, Yağ, Protein, Kuru Madde Verimleri, Süt Komponentleri ile Bazı Döl Verimi Özellikleri Arasındaki İlişkiler. Atatürk Üniv Ziraat Fak Derg, 33(3): 293-296.

Uslucan B 2017. Siyah Alaca Sığırlarda Süt Ve Döl Verim Özellikleri İle Bazı Davranış Parametreleri Üzerine Etkili Çevre Faktörlerinin Belirlenmesi. ÇÜ. Fen Bil. Ens., Zootekni ABD, Doktora Tezi, Adana.

Yue SJ, Zhao YQ, Gu XR, Yin B, Jiang YL, Wang ZH, Shi KR 2017. A Genome-Wide Association Study Suggests New Candidate Genes For Milk Production Traits in Chinese Holstein Cattle. Anim Genet, 10.1111/age.12593. 